\title{
NOTES ON THE RELATIONS BETWEEN THE EU AND UKRAINE AND THE PROGRESS IN THE IMPLEMENTATION OF THE ASSOCIATION AGREEMENT ${ }^{1}$
}

The 2014 Association Agreement between the EU and Ukraine, which replaces the 1994 Partnership and Cooperation Agreement, may be considered the most important result of a cooperation developed since the beginning of 90's, first in the framework of the European Neighbourhood Policy, then of the Eastern Partnership.

This paper analyses in an essential way the evolving relations between the EU and Ukraine, and the progress made by Ukraine in pursuing the objectives set forth in the Association Agreement. The Author considers the main features of the Agreement, and identifies and assesses the principal legal issues arising from its implementation.

The Agreement is aimed at deepening political and economic relations between the EU and Ukraine, and to gradually integrate Ukraine into the EU internal market. It is the first of a new generation of EU agreements characterized by comprehensiveness, and democratic conditionality. It requires a broad and detailed work of approximation of the Ukrainian laws to the EU regulations. Reforms are foreseen in a number of key areas.

Ukraine has been developing a complex strategy to reorient its legal system towards the EU. According to the 2018 Report on Implementation of the Association Agreement - prepared by the Government Office for Coordination of European and Euro-Atlantic Integration, and the Vice Prime Minister's Office for European and Euro-Atlantic Integration, based on the outcome of performance of the objectives scheduled for 2018, the Agreement was implemented by $52 \%$.

According to the Author, in evaluating the "results achieved" by Ukraine in the approximation of the national legislation to the EU legislation, it must be taken into account the challenging situation of the country. The Government and the Verkhovna Rada have been acting with the aim to pursue the overall objectives of the Association Agreement notwithstanding the difficult political and administrative situation following the events in Crimea, the Donbass conflict, the worsening of the relations with Russia until the termination of the Treaty of Friendship and the temporary adoption of the Martial Law.

He highlights the efforts of the EU in financially supporting the process of reform in Ukraine, and of Ukraine towards constitutional and legislative reforms reinforcing the European choice. Ukraine has finally developed an ad hoc institutional framework, and new legislation, including amendments to the Constitution, for the implementation of the Association Agreement.

Relevant progress has been made in various sectors of the cooperation, while in various others the actions taken are not yet effective. For example, in the sector of the rule of law,

${ }^{1}$ This paper is a result of a research started in Autumn 2018 thanks to a CNR STM (short term mobility), and developed within a broader project carried out at ISGI. The Author sincerely thanks the Faculty of Law of Taras Shevchenko National University of Kyiv, in Ukraine, where he has been working in a welcoming and proactive environment. 
various actions were taken, but modest results were achieved in the fight against corruption; while in the environment sector, which is not considered among the priorities, the Law on EIA might be considered an important achievement.

In the whole, the implementation of the Association Agreement was evaluated positively at the highest level of political dialogue, by the 20th EU-Ukraine Summit (9 July 2018), and the 5th EU-Ukraine Association Council (Brussels, 17 December 2018).

In the Author's opinion, notwithstanding various critical points, the numerous constitutional and legislative acts, the regulations and the plans adopted in the period 2014-2018, represent important steps of a broad process of change. He underlines the importance to proceed focusing not just on the formal harmonization of the Ukrainian legal system to the EU law, but on the effectiveness and efficacy of the new rules, and their real implications on the social, economic, political and cultural heritage and life of people.

Key words: $E U$ - Ukraine relations, EU - Ukraine Association Agreement, Implementation of the Association Agreement, Ukraine reform process, environmental law. 


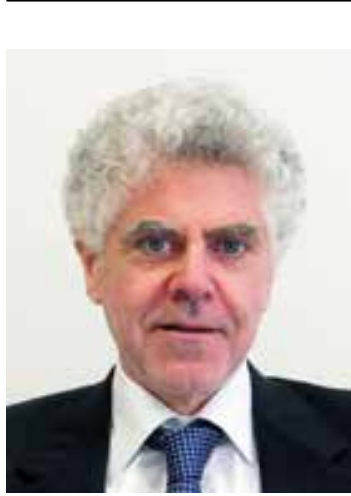

Gianfranco Tamburelli², Researcher and Team Leader of the Institute for International Legal Studies (ISGI) of the National Research Council (CNR) of Italy,

$P h D$ in International Law orcid.org/0000-0002-7226-9151 gianfranco.tamburelli@cnr.it

\section{Introduction}

The relations between the EU and Ukraine have been developing and strengthening since the adoption, in 1994, of the Partnership and Cooperation Agreement (PCA), which entered in force in 1998. In 2003, Ukraine became, together with Georgia and Moldavia, one of the European non-member countries to which is directed the European Neighbourhood Policy (ENP); then, in 2009, a priority partner in the context of the EU Eastern Partnership.

In 2012 the negotiations for an Association Agreement between the EU and its Member States, of the one part, and Ukraine, of the other part, were finalised.

This course of the relations between the EU and Ukraine appeared at risk when, in November 2013, the Ukrainian Government suspended the signing of the Association Agreement. A series of exceptional events followed: on the one hand, huge protest demonstration and the "Revolution of Dignity", the government changes, the new presidential and general elections; on the other hand, the declaration of independence of Crimea and its annexation to Russia, and the conflict between the new Government of Kyiv and the Eastern regions of Donetsk and Lugansk, where referendum on the autonomy were held.

However, on $27^{\text {th }}$ June 2014, the Association Agreement was signed, and on $16^{\text {th }}$ September 2014 it was ratified by Ukraine and consent was given by the European Parliament.

The Agreement imposes on Ukraine the pursuit of a series of goals, and the passing of reforms concerning the rule of law, democracy, and basic human freedoms (Article 2). It has been considered, together with the Association Agreements stipulated by the EU with Georgia and Moldova, a milestone in the history of Europe as a whole, and also an innovative legal instrument providing for a new type of integration without membership (Van der Loo, 2014).

After a few years since its adoption, provisional implementation and, finally, entry into force, an analysis of the evolving relations between the EU and Ukraine, and of the progress

${ }^{2} \mathrm{PhD}$ in International Law, he is a Member of the Ordine degli Avvocati (equivalent of the Bar Council) of Rome, and of the Italian Society of International and EU Law (SIDI). He is working at the Institute for International Legal Studies (ISGI) of the National Research Council of Italy (CNR). He is, among other things, a Member of the World Commission on Environmental Law (WCEL) of the World Conservation Union, a member of the Scientific Committee of the International Court Environment Foundation (ICEF), the Representative of the CNR at the EUROPARC Federation, a Professor of the Faculty of Law of Taras Shevchenko National University of Kyiv, a Professor of the Master in Environmental Law at Sapienza University of Rome. 
made by Ukraine in pursuing the objectives set forth in the Agreement, seems therefore, of great interest. With this aim, I will consider the main features of the Agreement and, taking into account its model character (it served to a large extent as a template for the agreements with Georgia and Moldova), I will identify and assess the main legal issues arising from its implementation, and the first results achieved in the approximation of the Ukrainian legislation to the EU acquis.

\section{The Association Agreement between the $\mathbf{E}$ and Ukraine}

The Association Agreement, which replaces the PCA, may be considered the most important result of a cooperation developed since the beginning of 1990's, first in the framework of the ENP, then of the Eastern Partnership. It is the first agreement based on political association between the EU and any of the Eastern Partnership countries, and is characterized by its breadth (number of areas covered) and depth (detail of commitments and timelines).

The comprehensive, and complex nature of the Association Agreement, and its political and strategic relevance, are reflected in the choice of the legal basis. We may observe that Article 8 (The Union and Its Neighbours) of the Treaty on the EU (TEU), endows the EU with an explicit competence to develop a special relationship with neighbouring countries, aiming at establishing an area of prosperity and good neighbourliness, founded on the values of the Union and characterized by close and peaceful relations. The EU Council Decision on the signing and provisional application of the political provisions of the Association Agreement, adopted on $17^{\text {th }}$ March 2014, does not however, refer to Article 8; it instead combines the traditional provision on Association (Article 217, Treaty on the Functioning of the EU-TFEU) ${ }^{3}$ with the legal basis for EU action in the area of Common Foreign and Security Policy (Article 31.1, and Article 37 TEU).

In line with the principles guiding EU foreign policy, one of the main characters of the Agreement is the so-called democratic conditionality ${ }^{4}$. This requires the inclusion of conditionality clauses, according to which if the third State violates standards of human rights or is guilty of serious violations of human rights, the EU reserves the right to suspend or terminate the agreement (Article 478, Appropriate measures in case of non-fulfillment of obligations).

The Agreement aims to deepen political and economic relations between the EU and Ukraine, and to gradually integrate Ukraine into the EU internal market. With regard to the principles affirmed, it puts a strong emphasis on democracy and the rule of law, human rights and fundamental freedoms, good governance, a well-functioning market economy and sustainable development.

\footnotetext{
${ }^{3}$ According to Article 217 of the TFUE (Treaty on the Functioning of the EU), the association agreements involve "reciprocal rights and obligations, common actions and special procedure".

${ }^{4}$ Before the 90 s, all EC economic agreements were inspired by the so-called "ideological neutrality": the EC, in entertaining relations, did not take into account if the third State was or was not respectful of human rights, the rule of law, democracy. In 1991 the European Council held in Luxembourg introduced a new policy, confirmed by Article 6 of the 1992 Treaty of Maastricht, indicating the parameters that would guide the action of the EC with third countries. Since then, co-operation has become the primary instrument for the promotion outside of the values of democracy, respect for human rights and affirmation of the rule of law; financial aid has been granted to third State under the condition of the undertaking of agreed policies.
} 
In expectation of the completion of the ratification procedure by EU Member States, the Agreement provisions concerning the respect for human rights, fundamental freedoms and rule of law; political dialogue and reform; justice, freedom and security; economic and financial cooperation were provisionally applied since $1^{\text {st }}$ November 2014. The provisional application of the DFCTA - Deep and Comprehensive Free Trade Area was delayed until

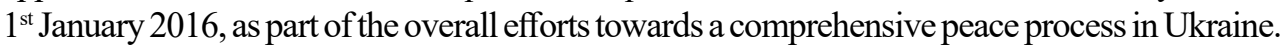

The Agreement finally, entered into force on $1^{\text {st }}$ September 2017.

The EU Association Agreements with Georgia and Moldova include a general provision on the "territorial application", stating that "the application of the DFCTA in relation to those areas over which the Government does not exercise effective control" shall commence once Georgia/Moldova will be able to ensure the full implementation and enforcement of the DFCTA, in their entire territory.

The Association Agreement between the EU and Ukraine doesn't address the issue. The EU and Ukraine agreed however, in the Final Act, that the Association Agreement shall apply to the entire territory of Ukraine as recognized under international law and they "shall engage in consultations with a view to determine the effects of the Agreement with regard to the illegally annexed territory of the Autonomous Republic of Crimea and the City of Sevastopol in which the Ukraine Government does not exercise effective control". To overcome the problem of treatment of products exported from the region, the EU prohibited the imports of goods from Crimea and Sevastopol (cf. Council Decision № 386/CFSP of 23 June 2014. This Decision has been amended several times and renewed until 23 June 2019 by Council Decision № 880 of 18 June 2018).

The EU - Ukraine Association Agreement contains numerous provisions affirming the principles of independence, sovereignty, territorial integrity and inviolability of borders. The Parties declare their commitment to the promotion of those principles in the Preamble, and to the promotion of their respect in Article 2 (Title I, General Principles), according to which they constitute essential elements of the Agreement.

Furthermore, the strengthening of political dialogue between the Parties in all areas of mutual interest should "promote gradual convergence on foreign and security matters with the aim of Ukraine's ever-deeper involvement in the European security area" (Article 4).

The relevant provisions of the UN Charter and the 1975 Helsinki Final Act of the Conference on Security and Cooperation in Europe are also recalled by Article 7 (Foreign and Security Policy, 2).

In this regard, we may note that the EU has strongly condemned the illegal annexation of Crimea and Sevastopol to the Russian Federation for the violation of the sovereignty and territorial integrity of Ukraine, and "will not recognize it". On its side, Ukraine regards the territory of Crimea as a "temporary occupied territory" (Verkhovna Rada of Ukraine, 2014).

3. Institutional framework for the implementation of the Association Agreement

Summit meetings, which will take place once a year, shall provide overall guidance for the implementation of the Association Agreement (Article 460). In addition, the Agreement establishes the Association Council and the Association Committee (Articles 461-466), the Parliamentary Association Committee (Articles 467-468), and the Civil Society Platform (Article 469-470). 
The Association Council supervises the implementation of the Agreement, and may examine any major issues arising within its framework, and any other bilateral or international issues of mutual interest. It is empowered to make recommendations and decisions to pursue the objectives of the Agreement. In particular, the Association Council may update or amend the Annexes of the Agreement, taking into account the development of the EU law and applicable standards set out in international instruments.

It is composed by the members of the Council of the EU, members of the European Commission, and members of the Cabinet of Ukraine (Cabinet of Ministers of Ukraine, 2014). It shall meet at the ministerial level at least once a year or according to the specific circumstances, and shall be chaired in turn by a representative of Ukraine and of the EU.

The Association Committee shall assist the Association Council in the performance of its duties. It has the power to adopt decisions in some specific cases provided for in the Agreement, and when delegated by the Association Council. It is composed by representative of the Parties at senior civil servant level. For Ukraine, the members of the Association Committee are the Deputy Ministers responsible for European integration issues, the Deputy Minister of Economic Development and Trade, as well as the deputy heads of other executive authorities with competences related to the implementation of the Association Agreement (the EU-Ukraine Association Committee met on 13-15 July 2015 in Brussels; on 5-6 July 2016 in Kyiv; on 29-30 June 2017 in Brussels; on 5 October 2018 in Kyiv).

The Decisions of the Association Council, and those of the Association Committee, shall be binding upon the Parties, which shall adopt appropriate measures to implement them. The legal nature of these decisions might be argued. In my opinion, the fact that the binding decisions of the Association Council and the Association Committee are adopted by agreement and following completion of the respective internal procedures, leads to consider them as international agreements in simplified form. A specific issue might however, arise from these binding decisions, whenever they will be adopted, because international agreements lack of direct enforceability in the Ukrainian legal order.

\section{The Association Agreement and the Ukrainian legal system: first issues}

Various legal and judicial issues have arisen for Ukraine in the course of implementing the Association Agreement into its legal system. Since the very beginning, the question arose about the value of the EU acquis, including the case law of the Court of Justice (CJEU), in the Ukrainian legal system. In November 2014, the Ukrainian High Administrative Court interestingly stated that the EU law and the case law of the CJEU couldn't be considered as part of the Ukrainian legal system; however, "legal positions as they are formalized in decisions of the CJEU can be taken into consideration by administrative courts as argumentation, reflection regarding harmonious interpretation of Ukrainian legislation in line with established standards of the EU legal system"s.

On 2 June 2016, the Law on Amending the Constitution of Ukraine envisaged the abolition of the system of high specialized courts, thereby undermining the value of this judgement by the High Administrative Court. It however introduced some provisions aimed to avoid one of the possible conflicts between some provisions of the Association Agreement

\footnotetext{
${ }^{5}$ Kyiv District Administrative Court Judgment № 2/416 of 25 November 2008.
} 
and the Ukrainian Constitution (Petrov, 2018). It had in fact been argued that the provisions of Article 8 of the Association Agreement, binding Ukraine to ratify and implement the Rome Statute on the International Criminal Court (ICC) and its related instruments, were imposing commitments on Ukraine which contradict the national Constitution. In particular, because the provision in Article 1 of the Statute affirms that the ICC shall be complementary to national criminal jurisdictions, while the Ukrainian Constitution prohibits delegation of judicial powers to bodies other than the Ukrainian courts, and establishment of new courts that are not provided in the Constitution ${ }^{6}$.

In a Judgment of $11^{\text {th }}$ November 2001 (case № 1-35), the Constitutional Court of Ukraine had in fact affirmed that several provisions of the Rome Statute were not in conformity with the national Constitution. To overcome this judgment, the new text of Article 124 of the Constitution, as amended, include a specific provision reading: Ukraine may recognize the jurisdiction of the International Criminal Court as provided for by the Rome Statute of the ICC (paragraph 6). This provision will become effective since 30 June 2019.

More generally, the 2016 Law was aimed to ensure the respect for the principle of the rule of law, and to pursue the efficiency, the independence and impartiality of the judiciary (Title III - Justice, Freedom and Security of the Association Agreement).

5. The European choice of Ukraine and the relations with the Russian Federation

In September 2018, with the intention to consolidate the Euro-Atlantic and EU choices of Ukraine at the level of the Constitution, the President introduced to the Parliament the draft Law № 9037, on the Strategic Course of the State towards Ukraine's Full Membership in the EU and the North Atlantic Treaty Organization (NATO).

On $20^{\text {th }}$ September 2018, the Parliament voted to submit the presidential draft Law to the Constitutional Court, which adopted a positive Opinion on the compliance of the draft Law with Articles 157 and 158 of the Constitution (Constitutional Court of Ukraine, 2018), giving "green light" for its adoption.

Then, on $22^{\text {nd }}$ November 2018, the Parliament preliminarily approved the Law, which provides for the declaration, at the Preamble level, of the European identity of the Ukrainian people and the irreversibility of the European and Euro-Atlantic course of Ukraine ${ }^{7}$. The Law, finally signed by the President of Ukraine on 7th February 2019, defines the powers of the Parliament, as well as of the Government and the President, in developing and implementing the EU and Euro-Atlantic course of the State. According to some comments, these amendments would have required further analysis (Kyrychenko, 2019).

\footnotetext{
${ }^{6}$ Ukraine is not yet a party to the Rome Statute. Nevertheless, on 17 April 2014, the Government accepted the ICC's jurisdiction over alleged crimes committed on its territory from 21 November 2013 to 22 February 2014. On 8 September 2015, the Government lodged a second declaration under Article 12 (3) of the Statute accepting the exercise of jurisdiction by the ICC in relation to alleged crimes committed on its territory from February 2014 onwards, with no end date. Info at the website of the ICC: https://www.icc-cpi.int/ukraine.

7 The $5^{\text {th }}$ preamble paragraph has been supplemented with the words "and confirming the European identity of the Ukrainian people and the irreversibility of the European and Euro-Atlantic course of Ukraine".
} 
Ukraine has been developing a complex strategy to reorient its legal system towards the EU, facing at the same time the worsening of the relations with the Russian Federation. In this context, on $6^{\text {th }}$ September 2018 the Council of National Security and Defense adopted a Decision to suspend Ukraine from the Treaty on Friendship, Cooperation and Partnership between Ukraine and the Russian Federation, and to declare to the Russian Federation the desire of Ukraine to terminate it (in accordance with Article 40 of the Treaty itself). To implement the Decision, the President adopted, according to Article 107 of the Constitution, the Decree № 284 of $17^{\text {th }}$ September 2018, and introduced to the Verkhovna Rada the draft Law № 206 of $3^{\text {rd }}$ December 2018.

On $6^{\text {th }}$ December 2018, the Verkhovna Rada passed the Law, which provides for the termination of the Treaty from $1^{\text {st }}$ April 2019, and the President signed it on $10^{\text {th }}$ December 2018. The explanatory note to the draft Law states that "the ongoing aggression of the Russian Federation caused significant violations of most of the Treaty's articles", and that there are no signs of Russia's good faith to eliminate violations and compensate for the damage caused (Poroshenko proposes terminating Treaty of Friendship with Russia, 2018). The termination of the Treaty is expected to facilitate proper and effective protection of the national interests of Ukraine, and the strengthening of the relations with the EU. According to the President, the non-renewal of the Treaty with Russia should not be viewed as an episode, but "as part of our strategy for a final break with the colonial past and reorientation towards Europe $<\ldots>$ other components of this strategy are: visa-free, Association Agreement with the EU, Tomos on the creation of an autocephalous independent Ukrainian church, enshrined in the Constitution on accession to NATO and the EU $<\ldots>$ " (President of Ukraine signed a law on the termination of friendship with Russia, 2018).

The ongoing conflict in the Eastern Regions was also at the base of the Martial Law introduced for a 30-day period, from $26^{\text {th }}$ November 2018, and effective in Vinnytsia, Luhansk, Mykolaiv, Odesa, Sumy, Kharkiv, Chernihiv, Donetsk, Zaporizhzhia, Kherson regions, and the Ukrainian inland waters of the Azov-Kerch water area. According to this Law, entry to Ukraine to male citizens of the Russian Federation aged 16 to 60 years was temporarily prohibited (from $30^{\text {th }}$ November 2018), as well as entry to Crimea was prohibited for foreigners. Furthermore, States authorities had the right to impose various restrictions on nationals (from, among others, confiscating property, vehicles, machinery and equipment for the needs of the State, to restricting the scope of information that may be disseminated by the media).

6. The implementation of the Association Agreement in the Ukrainian legal system

The implementation of the Association Agreement requires a broad and detailed work of approximation of the Ukrainian laws to the EU regulations. Reforms are foreseen in a number of key areas: public governance, justice, law enforcement, consumer protection, and economic sectors such as: energy, transport, environmental protection, industrial development, social development and protection, education, youth, culture.

In order to ensure efficient coordination of the public policy in this sphere, the Government Office for European Integration was established in the Secretariat of the Cabinet of Ministers of Ukraine; and positions of Deputy Ministers on European integration were introduced (Klympush-Tsintsadze, 2019). 
Among the numerous acts adopted, we might mention the Resolution of the Cabinet of Ministers № 847 of $17^{\text {th }}$ September 2014, on the Action Plan on Implementation of the Association Agreement for the Years 2014-2017, and the Resolution of 25th October 2017, on the Action Plan on Implementation of the Association Agreement for the Years 2018-2020, as well as the Resolution of $31^{\text {st }}$ May 2017, on the Procedure for Planning, Monitoring and Assessing the Implementation of the Association Agreement. These Resolutions are binding on the ministries and other executive agencies.

According to the Report on Implementation of the Association Agreement between Ukraine and the EU 2018 - prepared by the Government Office for Coordination of European and Euro-Atlantic Integration, and the Vice Prime Minister's Office for European and Euro-Atlantic Integration, based on the outcome of performance of the objectives scheduled for 2018, the Agreement was implemented by $52 \%$.

It seems opportune to develop an essential analysis of the progress made in some sector of the cooperation. For example, as regards the aim of achieving an improvement in the functioning of the judicial system and the rule of law, the relevant dispositions of the Agreement definitely set in motion an important series of reforming actions.

Following the constitutional amendments and legislative changes introduced in 2016, an entire new body of judges was appointed to the Supreme Court of Ukraine after completing a thorough procedure aimed at selecting candidates with the highest level of professional competence and personal integrity. With the adoption of the Law on the High Anti-Corruption Court in June 2018, the setting up of the specialized court also commenced.

However, I share the opinion of various international and EU observers according to whom there have been modest results in the fight against corruption; not only that of the judicial system, but also that of the 'renewed' political-institutional system. The Association Council itself, at its fifth meeting held in Brussels on 17 December 2018, reiterated that all anti-corruption institutions must carry out their work free from undue influence.

In the environment sector, which unfortunately is not considered among the priorities by the Association Council, the cooperation between the EU and Ukraine aims at preserving, protecting, improving, and rehabilitating the quality of the environment, protecting human health, prudent and rational utilisation of natural resources (Chapter 6, Environment, section on Economic and Industrial Cooperation of the Association Agreement).

Article 361 (Cooperation) identifies as areas of cooperation, inter alia: environmental governance and horizontal issues, including education and training, and access to environmental information and decision-making processes. Thus, the Environment Annex comprehends, among others, a section on environmental governance and integration of environment into other policy areas, and specific provisions concerning the timetable for the implementation of the EU EIA (environmental impact assessment) and SEA (strategic environmental assessment) Directives.

The EIA Directive applies to those public and private projects which are likely to have significant effects on the environment (Article 1. 1). It defines principles and procedures of the EIA, and promotes an overall consideration of the relationship between project and environment within the decision-making process. The main steps of the required procedure are: drafting of an environmental impact study by the proponent, consultation of the authorities concerned, information and public consultation, final evaluation and final decision. 
In April 2017, Ukraine adopted a new Law on EIA, which is "operative". This Law amended various legislative acts. Legal and organizational policies for the EIA have been defined with a view to avoid and prevent environmental damage, ensure environmental safety, environmental protection, and rational use and restoration of natural resources, in the process of decision-making on economic activity likely to cause a significant impact on the environment, taking into account state, public and private interests. The EIA shall be mandatory in the process of decision-making on carrying out the proposed activity identified in the Law (Article 3, Scope of application, paragraphs 2 and 3$)$.

According to Article 10 (Expert Commissions on EIA) the competent central authority and the competent local authority may establish expert commissions on EIA, members of which shall be appointed for a 3-year period. The competent authority shall maintain the roster of experts from which the members of the expert commissions can be appointed. In Italy, a similar Commission for the verification of the environmental impact EIA - SEA is placed at the functional dependencies of the Ministry for the Environment, Land and Sea Protection. It is composed by 40 Commissioners, including the President and the Secretary. It will make use of a technical committee placed at the functional dependencies of the same Ministry ${ }^{8}$.

On $20^{\text {th }}$ March 2018, the Verkhovna Rada also adopted Law № 2354-VIII on SEA, which has been enacted on $12^{\text {th }}$ October 2018. A SEA shall be carried out for draft public planning documents in the field of agriculture, forestry, fisheries, energy, industry, transport, waste management, water use, environmental protection, telecommunications, tourism, urban planning and land management schemes, and implementation of which require - in relation to the type of activity - an EIA, as well as for draft public planning documents which require an assessment in view of the likely effects on sites or objects of the nature-reserve fund or ecological network (Article 4).

The Law on EIA definitely represents an important step in the harmonization of the Ukrainian environmental legislation with the EU environmental acquis, while the Law on SEA requires further regulations to be effectively enacted, and a lot remain to be done in other sub-sectors. I. Klympush-Tsintsadze, Vice Prime Minister for European and Euro-Atlantic Integration, mentioned, as strategic documents introducing the European principles in various areas, the National Waste Management Strategy until 2030, the National Plan for Reducing Emissions from Large Combustion Plants, and the Energy Strategy of Ukraine 2035.

\section{Priority cooperation directions}

In the whole, the implementation of the Association Agreement, including the DCFTA, was evaluated positively at the highest level of political dialogue, by the $20^{\text {th }}$ EU-Ukraine Summit (9 July 2018), and by the $5^{\text {th }}$ the EU-Ukraine Association Council (Brussels, 17 December 2018) .

\footnotetext{
${ }^{8}$ Decree of the Ministry for the Environment, Land and Sea Protection, № 300 of 31 November 2018 .

${ }^{9}$ The Association Council previously met on 15 December 2014, then on 7 December 2015, on 19 December 2016, and on 8 December 2017 (first time after the entry into force of the Association Agreement).
} 
Four priority cooperation directions were identified and specified in detail in order to enhance political association and economic integration of Ukraine with the EU: digital market, customs policy, energy sector, as well as justice, freedom and security. The deepening of cooperation with the EU in the priority sectors, such as the energy sector, justice and internal affairs, customs matters and digital economy, were key discussion topics during the consultations at expert level held in the framework of the Ukrainian-Norwegian bilateral dialogue on the matters of European integration (Oslo, 11-13 June 2018), and also at the 13th meeting of the Permanent Ukrainian-Lithuanian Commission for European Integration (Vilnius, 19-20 April 2018).

The Council acknowledged the efforts of the Ukrainian authorities in the implementation of the justice sector reform, including the launch of the new Supreme Court. It affirmed the importance of further reforms in this area to ensure effectiveness, independence and transparency of the court system. The EU reaffirmed its continued commitment to support Ukraine with regard to the justice and civilian security sector reforms, through EU programmes and the work of the EU Advisory Mission. On 21st June 2018, the Law of Ukraine "On national security" № 2469-VIII was adopted, which provides for the reforming of Ukraine's security sector in line with the EU and NATO standards and the introduction of civil control within the security sector bodies.

\section{Conclusions}

The Association Agreement is the first of a new generation of EU agreements and is characterized, as underlined, by its comprehensiveness, and its conditionality. It can definitely be considered a milestone in the history of Europe and "the most advanced agreement of its kind ever negotiated by the EU"10.

It seems, instead, of doubtful legal and political value the above-mentioned reference to a new type of integration without membership. The Association Agreement does not clarify the perspectives of the relations between the EU and Ukraine. It can only be said that it has contributed and is contributing to the wider recognition of Ukraine as a European country, which shares with the EU Members States a common history and common values. This recognition is particularly important because the quality of "European State" is one of the essential preconditions of EU membership (Article 49 of the TEU) (Joint Declaration on the EU-Ukraine Association Agreement, 2008).

EU Members States do not share a common vision on the future of the EU relations with Ukraine. This is not surprisingly, considering that, particularly in the last decade, they have often manifested different positions on several priority legal and political issues, from some requirements concerning respect of fundamental EU values (protection of democracy, the rule of law) in Hungary and Poland ${ }^{11}$, to important aspects of their foreign policy, including relations with Ukraine, and Russia.

${ }^{10}$ Herman Van Rompuy, at that time President of the European Council, Press remarks, Brussels, 25 February 2013.

${ }^{11}$ See, among the last significant acts, the European Parliament Resolution of 1 March 2018 on the Commission's Decision to activate Article 7 (1) TUE as regards the situation in Poland (OJEU, C 119, 5 April 2019); and the European Parliament Resolution of 12 September 2018 on a proposal calling on the Council to determine, pursuant to Article 7 (1) of the Treaty on EU, the existence of a clear risk of a serious breach by Hungary of the values on which the Union is founded (2017/2131). 
In this context, it seems important to highlight the efforts of the EU in financially supporting the process of reform in Ukraine, as well as of Ukraine towards constitutional and legislative reforms reinforcing the European choice. In addition to the macro-financial assistance (MFA), the EU has supported Ukraine through several other instruments, including humanitarian aid, and technical assistance. Ukraine has benefitted from a total of $€ 2.8$ billion worth of EU MFA loans since 2014 (European Commission, 2018). In 2018, the scope of the financial and credit assistance from the EU amounted to over EUR 1.2 billion (Klympush-Tsintsadze, 2019).

In evaluating the "results achieved" by Ukraine in the approximation of the national legislation to the EU legislation, it must be taken into account the challenging situation of the country. The Government and the Verkhovna Rada have been acting with the aim to pursue the overall objectives of the Association Agreement notwithstanding the difficult political and administrative situation following the events in Crimea, the Donbass conflict, the worsening of the relations with Russia until the termination of the Treaty of Friendship and the temporary adoption of the above-mentioned Martial Law.

Ukraine has developed an ad hoc institutional framework for the implementation of the Association Agreement and new legislation, also amending the Constitution, to harmonize the national legal system with the EU acquis. Relevant progress has been made in various sectors of the cooperation, while in various others the actions taken are not yet effective. For example, in the sector of justice the fight to corruption has not yet become reliable, while in the environment sector, which unfortunately is not considered among the priorities, the above-mentioned Law on EIA represents an important step in the right direction, but a lot remain to be done in other fields. It is worth to note the adoption, on 28 February 2019, of Law of Ukraine "On the Fundamental Principles (Strategy) of the State Environmental Policy of Ukraine for the Period up to 2030". This Strategy will be in force from 1 January 2020 (Verkhovna Rada of Ukraine, 2019).

Finally, in my opinion, notwithstanding various critical and arguable points, the numerous constitutional and legislative acts, the regulations and the plans adopted in the period considered (2014-2018), represent important steps of a broad process of change. It will now be important to proceed focusing not just on the formal harmonization of the Ukrainian legal system to the EU acquis, but on the effectiveness and efficacy of the new rules, and their real implications on the social, economic, political and cultural heritage and life of people.

\section{Bibliography:}

1. Klympush-Tsintsadze I. Report on Implementation of the Association Agreement between Ukraine and the European Union in 2018 (is prepared by the Government Office for Coordination of European and Euro-Atlantic Integration with the support of the EU Delegation to Ukraine and Association4U Project funded by the European Union). Kyiv, 2019. 36 p. URL: https://www.kmu.gov.ua/storage/app/sites/1/55-GOEEI/AA_report_UA.pdf.

2. Kyrychenko Yu. Incorporation of the Euro- Atlantic Course in the Constitution Goes on in Ukraine. Centre of Policy and Legal Reform: official website. 2019. January 14. URL: http://pravo.org.ua/en/news/20873466-incorporation-of-the-euro-atlantic-course-in-the-constitution-goes-on-in-ukraine. 
3. Wolczuk K. The Development of an Institutional Framework for the Implementation of the Association Agreements in Georgia, Moldova and Ukraine: a comparative perspective. Luxembourg : Policy Department for External Relations, Directorate General for External Policies of the Union, 2018. 63 p. URL: http://www.europarl.europa.eu/RegData/etudes/STUD/2018/603879/ EXPO_STU(2018)603879_EN.pdf.

4. Petrov R. The Impact of the EU-Ukraine Association Agreement on Constitutional Reform and Judicial Activism in Ukraine. Review of Central and East European Law. 2018. Vol. 43. № 2. P. 99-115.

5. Zygierewicz A. Association Agreements between the EU and Moldova, Georgia, and Ukraine: European Implementation Assessment. Brussels : European Parliamentary Research Service, 2018. 244 p. URL: http://www.europarl.europa.eu/RegData/etudes/STUD/2018/621833/ EPRS_STU(2018)621833_EN.pdf.

6. Van der Loo G. The EU's Association Agreements and DCFTAs with Ukraine, Moldova and Georgia: a comparative study. Understanding the EU's Association Agreements and Deep and Comprehensive Free Trade Areas with Ukraine, Moldova and Georgia. 2017. URL: http://www.3dcftas.eu/system/tdf/Comparitve\%20GVDL\%2024.6.17_final_0.pdf?file=1\&type $=$ node $\&$ id $=360$.

7. Support Group for Ukraine. Activity Report: the first 18 months. Brussels : European Commission, 2016. 25 p. URL: https://ec.europa.eu/neighbourhood-enlargement/sites/near/files/ neighbourhood/pdf/key-documents/ukraine/20161028-report-sgua.pdf.

8. Evola M. The EU-Ukrainian Association Agreement between the European Neighborhood Policy and Admission. Il diritto dell'Unione Europea. 2015. URL: http://www.dirittounioneeuropea.eu/eu-ukraine-association-agreement-european-neighbourhood.

9. Van der Loo G., Van Elsuwege P., Petrov R. The EU-Ukraine Association Agreement: assessment of an innovative legal instrument. Working Papers of the Law Department of the European University Institute. 2014. № 9. URL: https://cadmus.eui.eu/bitstream/handle/1814/32031/ LAW\%20_WP_2014_9\%20.pdf?sequence=1\&isAllowed=y.

10. Comelli M., Pirozzi N. La Politica estera dell'Unione europea dopo Lisbona. Osservatorio di Politica internazionale. 2013. № 72. URL: http://www.iai.it/sites/default/files/pi_a_0072.pdf.

11. Commission of the European Communities. Eastern Partnership : Communication from the Commission to the Council and the European Parliament, $\operatorname{COM}(2008) 823$ final. Brussels, 2008. URL: http://www.epgencms.europarl.europa.eu/cmsdata/upload/668e28f3-9e29-4a41b376-43acaeff76ec/EaP_COM(2008)823.pdf.

12. Commission of the European Communities. Wider Europe - Neighbourhood: A New Framework for Relations with our Eastern and Southern Neighbours : Communication from the Commission to the Council and the European Parliament, COM(2003) 104 final. Brussels, 2003. URL: http://eeas.europa.eu/archives/docs/enp/pdf/pdf/com03_104_en.pdf.

13. Про забезпечення прав і свобод громадян та правовий режим на тимчасово окупованій території України : Закон України від 15 квітня 2014 р. № 1207-VII / Верховна Рада України. URL: https://zakon.rada.gov.ua/laws/show/1207-18.

14. Питання підготовки та проведення засідань окремих двосторонніх органів асоціації між Україною та ЄС : Постанова Кабінету Міністрів України від 10 грудня 2014 р. № 700 / Кабінет Міністрів України. URL: https:/zakon.rada.gov.ua/laws/show/700-2014-п.

15. Висновок Конституційного Суду України у справі за конституційним зверненням Верховної Ради України про надання висновку щодо відповідності законопроекту про внесення змін до Конституції України (щодо стратегічного курсу держави на набуття повноправного членства України в Європейському Союзі та в Організації Північноатлантичного договору) (реєстр. № 9037) вимогам статей 157 і 158 Конституції України від 22 листопада 2018 p. № 3-в/2018 / Конституційний Суд України. URL: http://www.ccu.gov.ua/sites/default/ files/docs/3_v_2018.pdf. 
16. Poroshenko proposes terminating Treaty of Friendship with Russia from April 1, 2019. UNIAN: Information Agency. 2018. December 3. URL: https://www.unian.info/ politics/10361844-poroshenko-proposes-terminating-treaty-of-friendship-with-russia-from-april-1-2019.html.

17. President of Ukraine signed a law on the termination of friendship with Russia. Forum Daily: Voice of Russian-Speaking America. 2018. December 10. URL: http://www.forumdaily. com/en/prezident-ukrainy-podpisal-zakon-o-prekrashhenii-druzhby-s-rossiej.

18. Joint Declaration on the EU-Ukraine Association Agreement. EU-Ukraine Summit, Paris, 9 September 2008 (12812/08). Brussels : Council of the EU, 2008. P. 2-4. URL: https://www.consilium.europa.eu/ueDocs/cms_Data/docs/pressData/en/er/102633.pdf.

19. European Commission. EU Approves Disbursement of $€ 500$ million in MacroFinancial Assistance to Ukraine: Press Release (30 November 2018). Brussels, 2018. URL: https://europa.eu/rapid/press-release_IP-18-6600_en.htm.

20. Про Основні засади (стратегію) державної екологічної політики України на період до 2030 року : Закон України від 28 лютого 2019 р. № 2697-VIII / Верховна Рада України. URL: https://zakon.rada.gov.ua/laws/show/2697-19.

\section{References:}

1. Klympush-Tsintsadze, I. (2019). Report on Implementation of the Association Agreement between Ukraine and the European Union in 2018 (is prepared by the Government Office for Coordination of European and Euro-Atlantic Integration with the support of the EU Delegation to Ukraine and Association4U Project funded by the European Union). Kyiv. Retrieved from: https://www.kmu.gov.ua/storage/app/sites/1/55-GOEEI/AA_report_UA.pdf [in English].

2. Kyrychenko, Yu. (2019). Incorporation of the Euro- Atlantic Course in the Constitution Goes on in Ukraine. Centre of Policy and Legal Reform: official website. Retrieved from: http://pravo.org.ua/en/news/20873466-incorporation-of-the-euro-atlantic-course-in-the-constitution-goes-on-in-ukraine [in English].

3. Wolczuk, K. (2018). The Development of an Institutional Framework for the Implementation of the Association Agreements in Georgia, Moldova and Ukraine: a comparative perspective. Luxembourg: Policy Department for External Relations, Directorate General for External Policies of the Union. Retrieved from: http://www.europarl.europa.eu/RegData/etudes/ STUD/2018/603879/EXPO_STU(2018)603879_EN.pdf [in English].

4. Petrov, R. (2018). The Impact of the EU-Ukraine Association Agreement on Constitutional Reform and Judicial Activism in Ukraine. Review of Central and East European Law, vol. 43, no. 2, pp. 99-115 [in English].

5. Zygierewicz, A. (2018). Association Agreements between the EU and Moldova, Georgia, and Ukraine: European Implementation Assessment. Brussels: European Parliamentary Research Service. Retrieved from: http://www.europarl.europa.eu/RegData/etudes/STUD/2018/621833/ EPRS_STU(2018)621833_EN.pdf [in English].

6. Van der Loo, G. (2017). The EU's Association Agreements and DCFTAs with Ukraine, Moldova and Georgia: a comparative study. Understanding the EU's Association Agreements and Deep and Comprehensive Free Trade Areas with Ukraine, Moldova and Georgia. Retrieved from: http://www.3dcftas.eu/system/tdf/Comparitve\%20GVDL\%2024.6.17_final_0.pdf?file=1\&type $=$ node \&id=360 [in English].

7. Support Group for Ukraine (2016). Activity Report: the first 18 months. Brussels: European Commission. Retrieved from: https://ec.europa.eu/neighbourhood-enlargement/sites/near/ files/neighbourhood/pdf/key-documents/ukraine/20161028-report-sgua.pdf [in English]. 
8. Evola, M. (2015). The EU-Ukrainian Association Agreement between the European Neighborhood Policy and Admission. Il diritto dell'Unione Europea. Retrieved from: http:// www.dirittounioneeuropea.eu/eu-ukraine-association-agreement-european-neighbourhood [in English].

9. Van der Loo, G., Van Elsuwege, P., Petrov, R. (2014). The EU-Ukraine Association Agreement: assessment of an innovative legal instrument. Working Papers of the Law Department of the European University Institute, no. 9. Retrieved from: https://cadmus.eui.eu/bitstream/handle/1814/32031/LAW\%20_WP_2014_9\%20.pdf?sequence=1\&isAllowed=y [in English].

10. Comelli, M., Pirozzi, N. (2013). La Politica estera dell'Unione europea dopo Lisbona. Osservatorio di Politica internazionale, no. 72. Retrieved from: http://www.iai.it/sites/default/ files/pi_a_0072.pdf [in Italian].

11. Commission of the European Communities (2008). Eastern Partnership: Communication from the Commission to the Council and the European Parliament, COM(2008) 823 final. Brussels. Retrieved from: http://www.epgencms.europarl.europa.eu/cmsdata/upload/668e28f3-9e29-4a41b376-43acaeff76ec/EaP_COM(2008)823.pdf [in English].

12. Commission of the European Communities (2003). Wider Europe - Neighbourhood: A New Framework for Relations with our Eastern and Southern Neighbours: Communication from the Commission to the Council and the European Parliament, COM(2003) 104 final. Brussels. Retrieved from: http://eeas.europa.eu/archives/docs/enp/pdf/pdf/com03_104_en.pdf [in English].

13. Verkhovna Rada of Ukraine (2014). Pro zabezpechennia prav i svobod hromadian ta pravovyi rezhym na tymchasovo okupovanii terytorii Ukrainy: Zakon Ukrainy vid 15 kvitnia 2014 r. № 1207-VII [On Ensuring the Rights and Freedoms of Citizens and the Legal Regime in the Temporarily Occupied Territory of Ukraine: Law of Ukraine of April 15, 2014 № 1207-VII]. Retrieved from: https://zakon.rada.gov.ua/laws/show/1207-18 [in Ukrainian].

14. Cabinet of Ministers of Ukraine (2014). Pytannia pidhotovky ta provedennia zasidan okremykh dvostoronnikh orhaniv asotsiatsii mizh Ukrainoiu ta YeS: Postanova Kabinetu Ministriv Ukrainy vid 10 hrudnia 2014 r. № 700 [Issues of preparation and holding of meetings of separate bilateral bodies of the Association between Ukraine and the EU: Resolution of the Cabinet of Ministers of Ukraine of December 10, 2014 № 700]. Retrieved from: https://zakon.rada.gov.ua/ laws/show/700-2014-ח [in Ukrainian].

15. Constitutional Court of Ukraine (2018). Vysnovok Konstytutsiinoho Sudu Ukrainy u spravi za konstytutsiinym zvernenniam Verkhovnoi Rady Ukrainy pro nadannia vysnovku shchodo vidpovidnosti zakonoproektu pro vnesennia zmin do Konstytutsii Ukrainy (shchodo stratehichnoho kursu derzhavy na nabuttia povnopravnoho chlenstva Ukrainy v Yevropeiskomu Soiuzi ta v Orhanizatsii Pivnichnoatlantychnoho dohovoru) (reiestr. № 9037) vymoham statei 157 i 158 Konstytutsii Ukrainy vid 22 lystopada 2018 r. № 3-в/2018 [Opinion of the Constitutional Court of Ukraine in the case on the constitutional appeal of the Verkhovna Rada of Ukraine on the opinion on the conformity of the draft law on amendments to the Constitution of Ukraine (concerning the strategic course of the state for the acquisition of full membership of Ukraine in the European Union and in the Organization of the North Atlantic Treaty) (reg. № 9037) to the requirements of Articles 157 and 158 of the Constitution of Ukraine of November 22, 2018 № 3-B/2018]. Retrieved from: http://www.ccu.gov.ua/sites/default/files/ docs/3_v_2018.pdf [in Ukrainian].

16. Poroshenko proposes terminating Treaty of Friendship with Russia from April 1, 2019. (2018). UNIAN: Information Agency, December 3. Retrieved from: https://www.unian. info/politics/10361844-poroshenko-proposes-terminating-treaty-of-friendship-with-russia-from-april-1-2019.html [in English].

17. President of Ukraine signed a law on the termination of friendship with Russia. (2018). Forum Daily: Voice of Russian-Speaking America, December 10. Retrieved from: 
http://www.forumdaily.com/en/prezident-ukrainy-podpisal-zakon-o-prekrashhenii-druzhbys-rossiej [in English].

18. Joint Declaration on the EU-Ukraine Association Agreement. (2008). EU-Ukraine Summit, Paris, 9 September 2008 (12812/08). Brussels: Council of the EU, pp. 2-4. Retrieved from: https://www.consilium.europa.eu/ueDocs/cms_Data/docs/pressData/en/er/102633.pdf [in English].

19. European Commission (2018). EU Approves Disbursement of $€ 500$ million in Macro-Financial Assistance to Ukraine: Press Release (30 November 2018). Brussels. Retrieved from: https://europa.eu/rapid/press-release IP-18-6600 en.htm [in English].

20. Verkhovna Rada of Ukraine (2019). Pro Osnovni zasady (stratehiiu) derzhavnoi ekolohichnoi polityky Ukrainy na period do 2030 roku : Zakon Ukrainy vid 28 liutoho 2019 r. № 2697VIII [On the Fundamental Principles (Strategy) of the State Environmental Policy of Ukraine for the Period up to 2030: Law of Ukraine of February 28, 2019 № 2697-VIII]. Retrieved from: https://zakon.rada.gov.ua/laws/show/2697-19 [in Ukrainian].

\title{
ПРИМІТКИ ЩОДО ВІДНОСИН МІЖ ЕС ТА УКРАЇНОЮ ТА ПРОГРЕС У ВИКОНАННІ УГОДИ ПРО АСОЩАЦЮЮ
}

\author{
Джанфранко Тамбуреллі, \\ науковий співробітник та керівник групи \\ Інституту міжнародних правових досліджень (ISGI) \\ Національної дослідницької ради (CNR) Італії, \\ кандидат наук з міжнародного права \\ orcid.org/0000-0002-7226-9151 \\ gianfranco.tamburelli@cnr.it
}

Угода про асочіацію між ЄС та Украйною 2014 р., яка прийшла на зміну Угоді про партнерство та співробітниитво 1994 р., може вважатися найважливішим результатом співпраці, яка розвивалася з початку 1990-х рр. спочатку в межах Європейської політики сусідства, а потім Східного партнерства.

У статі проаналізовано розвиток відносин між СС та Україною, а також прогрес, досягнутий Украӥною щцодо ичілей, визначених Угодою про асочіачію. Автор розглядає основні особливості Угоди про асоиіацію, а також визначає й оиінює основні правові питання, щзо виникають унаслідок їі виконання.

Угода фокусується на поглибленні політичних та економічних відносин між $Є С$ та Україною, а також на поступовій інтеграиії України увнутрішній ринок СС. Це перша зугод ЄС нового покоління, щу характеризується всебічністю й демократичною зумовленістю. Вона вимагає масштабної та детальної роботи щяодо наближення законодавства України до Регламенту СС. Реформи передбачаються в низці ключових напрямів.

Україна розробляє комплексну стратегію щуодо адаптації своєї правової системи до правової системи СС. Відповідно до Звіту про виконання Угоди про асоиіацію між Україною та ЄС за 2018 р., підготовленого Урядовим офісом координаиії європейської та євроатлантичної інтеграції та Віцее-прем'єр-міністром із питань європейської та євроатлантичної інтеграції, за результатами виконання цілеей, запланованих на 2018 р., Угоду про асоиіачію було виконано на $52 \%$.

Автор вважає, щзо під час оцінки «досягнутих» Україною результатів щзодо наближення національного законодавства до законодавства ЄС необхіно враховувати складну ситуацію в крайні. Уряд і Верховна Рада Украӥни діють із метою досягнення загальних иілей 


\section{ЗАРУБІЖНЕ АДМІНІСТРАТИВНЕ ПРАВО ТА ПРОЦЕС}

Угоди про асоиіацію, незважаючи на складну політичну й адміністративну ситуацію після подій у Криму, конфлікт на Донбасі, погіршення відносин із Росією, припинення Договору про дружбу та тимчасове прийняття воєнного стану.

У статті акиентується увага на зусиллях СС у фінансовій підтримиі прочесу реформ в Україні та зусиллях Украӥни щодо конститучійних $і$ законодавчих реформ, які посилюють прагнення щодо європейського вибору. Украйна нарешті розробила спеціальну інституційну базу та нове законодавство, у тому числі зміни до Конституиії Украйни, для імплементаціі Угоди про асоиіачію.

Досягнуто прогресу в різних галузях співпраці, проте водночас деякі вжиті заходи ще не принесли відповідних результатів. Наприклад, у галузі верховенства права було вжито низку заходів, однак у сфері боротьби з корупцією поки ще досягнуті скромні результати. У свою чергу в галузі навколишнього середовища, яка не розглядалася як пріоритетна, Закон України «Про оцінку впливу на довкілля» може вважатися важливим досягненням. Загалом виконання Угоди про асоціацію було позитивно оцінене на найвищзому рівні політичного діалогу на 20-му саміті Україна - СС (9 липня 2018 р.) та на 5-й Раді асоцііації Україна - СС (Брюссель, 17 грудня 2018 р.).

На думку автора, незважаючи на деякі критичні моменти, конститучійні та законодавчі акти, положення й плани, прийняті в період 2014-2018 рр., є важливими кроками на иляху до прочесу масштабних змін. У статті підкреслюється важливість зосередження уваги не лише на формальній гармонізації правової системи України з правом ЄС, а й на ефективності та дієвості нових норм і їхніх реальних наслідках для сочіальної, економічної, політичної й культурної спадщини та життя людей.

Ключові слова: відносини між СС та Україною, Угода про асоціацію між Україною та ЄС, виконання Угоди про асоціацію, процес реформування України, екологічне право. 